\title{
A STUDY OF WEIGHT GAIN IN THE FIRST YEAR OF LIFE
}

BY

\author{
JESSIE PARFIT \\ Institute of Social Medicine, Oxford
}

\section{INTRODUCTION}

The present investigation relating to 662 boys and 620 girls born in Oxford between 1944 and 1948 was designed to observe the relation of sex and birth weight to growth during the first year of postnatal life. A majority of the babies (702) came from one private and two municipal welfare clinics in the city; the remainder (580) attended the Institute of Social Medicine. The latter are also enrolled in the Child Health Survey and are the subjects of a more intensive study of growth and development during the first five years of life (Thwaites, 1950).

The babies attending the Institute of Social Medicine were seen for the first time at 4 weeks, and again at 3,6, 9, and 12 months. The remainder were brought to the clinics at monthly intervals. Since the two municipal clinics were held in the same room but on different days, only three different weighing scales (balance type) were used. Four persons were responsible for the records, but each baby was supervised by the same person; they were weighed naked on the same scales, and the weight was recorded to the nearest whole ounce. Although the mothers often failed to bring their children on the appointed dates, in most cases the first visit, due at one month, did not vary by more than a week from the correct day, and those due at $3,6,9$, and 12 months were rarely more than two weeks too early or too late. In the exceptional cases an estimated weight for the correct date has been obtained from a curve drawn through the five recorded weights. In the result, the weights used in this paper have been derived from actual weighing and from graphic estimation in the following proportions:

\begin{tabular}{c|c|c}
\hline Babies & Weighings & Estimations \\
\hline 651 & 5 & - \\
443 & 4 & 1 \\
129 & 3 & 2 \\
59 & 2 & 3 \\
\hline
\end{tabular}

No baby was included for whom there were less than five recorded weights, and graphic interpolation was therefore used only to correct for date, and never to fill up an incomplete record. 
Birth weights were obtained from the mothers on their first visits. In several cases it was possible to check this statement and no major discrepancies between the stated and the actual weight were detected. In view of this, and also of the work done by Asher and Fraser Roberts (1949), the stated birth weight was accepted in every case.

The social-class distribution of the fathers of babies attending the Institute of Social Medicine compared with that of all males in 1931 (Registrar-General, 1931) includes an excess in Class III and a corresponding deficit in Classes IV and V.

\begin{tabular}{c|cc}
\hline & \multicolumn{2}{c}{ Percentage } \\
\cline { 2 - 3 } Social Class & Institute Series & England and Wales \\
\hline I & 5 & 3 \\
II & 10 & 48 \\
III & 67 & 18 \\
IV & 10 & 17 \\
V & 8 & \\
\hline
\end{tabular}

It is likely, therefore, that it represents a better than average series. It should be noted, however, that owing to the extreme housing shortage in Oxford, less than half the families had a home of their own (Thwaites, 1950). No record of the father's occupation was kept by the Welfare Clinics, but since this part of the sample includes 206 babies from a private clinic and 496 from municipal clinics in a good residential area, it is probable that it also includes a relatively large number of babies in the higher social classes.

There was no record of birth rank in 11 per cent. of the cases attending Welfare Clinics. Apart from minor differences in the higher birth ranks, the remainder corresponded closely to the Institute cases of which $45 \cdot 9$ per cent. were first, and $31 \cdot 3$ per cent. second babies.

\begin{tabular}{c|cc}
\hline Records & Institute Series & Clinic Series \\
\hline No records & 5 (adopted) & $\begin{array}{c}74(11 \%) \\
628\end{array}$ \\
\hline With records & 575 & $\%$ \\
\hline Birth Rank & $\%$ & $45 \cdot 9$ \\
2 & $45 \cdot 9$ & $29 \cdot 3$ \\
3 & $31 \cdot 3$ & $15 \cdot 8$ \\
4 and over & $11 \cdot 6$ & $9 \cdot 1$ \\
\hline
\end{tabular}

In $42 \cdot 5$ per cent. of the records obtained from the Welfare Clinics there was no mention of the mother's age. Judging by the remainder the most noticeable difference between the two series is in respect of the mothers aged 40 and over. This difference may be due to a tendency on the part of Welfare Clinics to record 
unusual events (e.g. an exceptionally old mother) more often than " normal findings ",

\begin{tabular}{|c|c|c|}
\hline Records & Institute Series & Clinic Series \\
\hline $\begin{array}{l}\text { No records } \\
\text { With records }\end{array}$ & $\underset{575}{5}$ (adopted) & $\begin{array}{l}298(42 \cdot 5 \%) \\
404\end{array}$ \\
\hline Mother's Age & $\%$ & $\%$ \\
\hline $\begin{array}{l}20 \text { years } \\
20-24 \\
25-29 \\
30-34 \\
35-39 \\
40 \text { and over }\end{array}$ & $\begin{array}{r}3 \cdot 0 \\
19 \cdot 8 \\
31 \cdot 3 \\
25 \cdot 0 \\
17 \cdot 0 \\
3 \cdot 8\end{array}$ & $\begin{array}{r}3 \cdot 2 \\
20 \cdot 8 \\
26 \cdot 2 \\
26 \cdot 9 \\
16 \cdot 5 \\
6 \cdot 2\end{array}$ \\
\hline
\end{tabular}

\section{WEIGHT RECORDS}

In order to observe the effect of sex and birth weight on subsequent growth, six birth-weight groups and five age periods were defined and the records for each sex analysed separately. For convenience, the birth-weight groups (which range from $5 \frac{1}{2} \mathrm{lb}$. and under to $9 \frac{1}{2} \mathrm{lb}$. and over) have been numbered 5 to 10 (see Table II, p. 4).

When the serial weight records were arranged according to age and sex and the findings for the children attending the Institute and the Clinics were compared, only minor differences were detected. Since none of these was statistically significant the two series have been combined for all subsequent analyses.

TABLE I

Weights IN the First Year of Life

(A) COMPARISON OF 662 BOYS WITH 620 GIRLS (COMBINED SERIES)

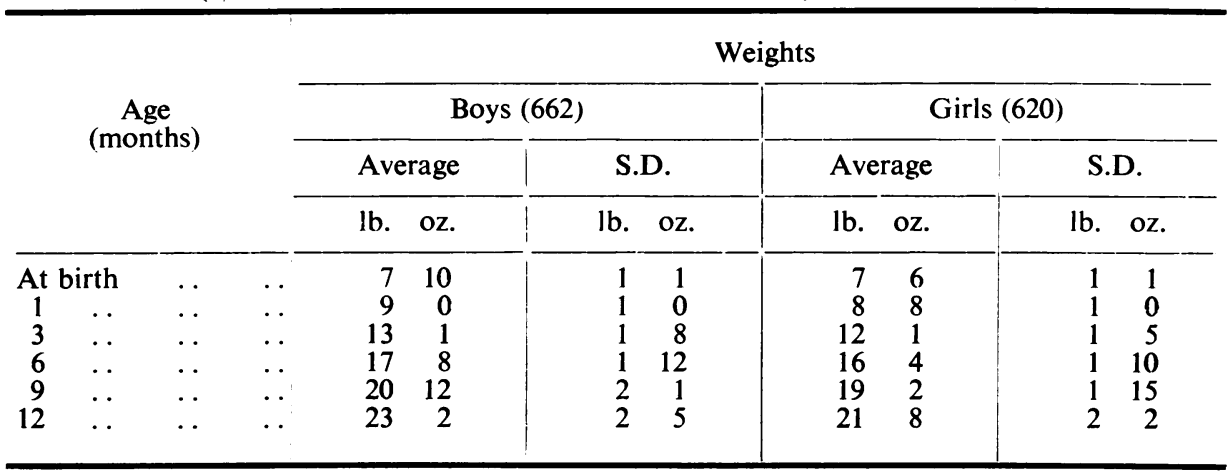

(A) Analysis by SeX

A direct comparison of the average weights at successive age periods revealed a significant difference* between the boys and girls which became progressively greater with increasing age (see Table I). Thus at birth the average weight of the

* Throughout this paper, the difference between two mean values is said to be significant if it is more than three times the standard error of the difference. 
boys exceeded that of the girls by $4 \mathrm{oz}$; by six months there was a difference of $20 \mathrm{oz}$, and at the end of the year the difference was $26 \mathrm{oz}$. This finding shows that the boys had grown faster than the girls prenatally (and so were heavier at birth) and that this difference in weight gain continued to increase for at least twelve months.

TABLE II

WeIGHTS* IN THE First YeAR OF LifE

(B) COMPARISON OF BOYS AND GIRLS IN SIX BIRTH-WEIGHT GROUPS

\begin{tabular}{|c|c|c|c|c|c|c|c|c|c|c|c|c|c|c|c|}
\hline \multirow{4}{*}{ Sex } & \multirow{4}{*}{$\begin{array}{c}\text { Group } \\
\text { No. }\end{array}$} & \multirow{4}{*}{$\begin{array}{c}\text { Range of } \\
\text { Birth } \\
\text { Weight }\end{array}$} & \multirow{4}{*}{$\begin{array}{l}\text { Total } \\
\text { Nos. }\end{array}$} & \multicolumn{10}{|c|}{ Average Weights* } & \multirow{2}{*}{\multicolumn{2}{|c|}{ At 12 months }} \\
\hline & & & & \multicolumn{2}{|c|}{ At Birth } & \multicolumn{2}{|c|}{ At 1 month } & \multicolumn{2}{|c|}{$\overline{\text { At } 3 \text { months }}$} & \multicolumn{2}{|c|}{ At 6 months } & \multicolumn{2}{|c|}{ At 9 months } & & \\
\hline & & & & $\overline{\begin{array}{c}\text { Aver- } \\
\text { age }\end{array}}$ & S.D. & $\begin{array}{c}\text { Aver- } \\
\text { age }\end{array}$ & S.D. & $\begin{array}{c}\text { Aver- } \\
\text { age }\end{array}$ & S.D. & $\begin{array}{c}\text { Aver- } \\
\text { age }\end{array}$ & S.D. & $\begin{array}{c}\text { Aver- } \\
\text { age }\end{array}$ & S.D. & $\begin{array}{c}\text { Aver- } \\
\text { age }\end{array}$ & S.D. \\
\hline & & & & lb. oz. & oz. & z. $1 \mathrm{b.oz}$. & lb. oz. & lb. oz. & lb. oz. & lb. oz. & lb. oz. & lb. oz. & 1b. oz. & \multicolumn{2}{|c|}{$\overline{\text { lb. oz. }} \overline{\text { lb. oz. }}$} \\
\hline \multirow{3}{*}{ Boys } & \multirow{3}{*}{\begin{tabular}{|r|}
5 \\
6 \\
7 \\
8 \\
9 \\
10
\end{tabular}} & \multirow{3}{*}{\begin{tabular}{|c|}
$5: 8$ \\
and under \\
$5: 9-6: 7$ \\
$6: 8-7: 7$ \\
$7: 8-8: 7$ \\
$8: 8-9: 7$ \\
$9: 8$ \\
and over
\end{tabular}} & \multirow{3}{*}{ 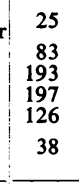 } & \multirow{3}{*}{\begin{tabular}{rr|}
4 & 14 \\
6 & 2 \\
7 & 2 \\
8 & 0 \\
8 & 14 \\
9 & 15
\end{tabular}} & & 615 & 013 & $\begin{array}{ll}10 & 2\end{array}$ & 15 & 145 & 110 & 1711 & 111 & 1915 & 25 \\
\hline & & & & & & \begin{tabular}{|r|r|}
7 & 9 \\
8 & 10 \\
9 & 6 \\
9 & 12
\end{tabular} \mid & $\begin{array}{ll}0 & 14 \\
0 & 15 \\
1 & 0 \\
0 & 15\end{array}$ & \begin{tabular}{rr|}
11 & 12 \\
12 & 12 \\
13 & 7 \\
13 & 15
\end{tabular} \mid & $\begin{array}{ll}1 & 8 \\
1 & 4 \\
1 & 9 \\
1 & 8\end{array}$ & $\begin{array}{rr}16 & 4 \\
17 & 3 \\
17 & 14 \\
18 & 9\end{array}$ & $\begin{array}{ll}1 & 14 \\
1 & 11 \\
1 & 13 \\
1 & 9\end{array}$ & $\begin{array}{rr}19 & 9 \\
20 & 2 \\
21 & 2 \\
21 & 12\end{array}$ & $\begin{array}{rr}2 & 2 \\
1 & 13 \\
2 & 3 \\
2 & 3\end{array}$ & $\begin{array}{rr}21 & 15 \\
22 & 5 \\
23 & 9 \\
24 & 7\end{array}$ & $\begin{array}{ll}2 & 4 \\
2 & 2 \\
2 & 3 \\
2 & 9\end{array}$ \\
\hline & & & & & $\begin{array}{ll}0 & 8\end{array}$ & 1014 & 12 & 1414 & 17 & 197 & 21 & 2214 & 25 & 258 & 26 \\
\hline & 5 & $\begin{array}{c}5: 8 \\
\text { and under }\end{array}$ & 33 & 51 & 07 & 67 & 012 & 104 & 14 & 149 & 19 & 179 & 113 & 197 & 22 \\
\hline irls & $\begin{array}{r}6 \\
7 \\
8 \\
9 \\
10\end{array}$ & $\begin{array}{c}5: 9-6: 7 \\
6: 8-7: 7 \\
7: 8-8: 7 \\
8: 8-9: 7 \\
9: 8\end{array}$ & $\begin{array}{r}96 \\
213 \\
195 \\
69 \\
14\end{array}$ & $\begin{array}{rr}6 & 2 \\
7 & 0 \\
7 & 15 \\
8 & 13 \\
9 & 14\end{array}$ & $\begin{array}{ll}0 & 4 \\
0 & 4 \\
0 & 5 \\
0 & 4 \\
0 & 5\end{array}$ & \begin{tabular}{|rr}
7 & 6 \\
8 & 5 \\
8 & 15 \\
9 & 12 \\
10 & 12
\end{tabular} & $\begin{array}{lr}0 & 11 \\
0 & 12 \\
1 & 2 \\
0 & 12 \\
0 & 10\end{array}$ & $\begin{array}{rr}11 & 0 \\
11 & 14 \\
12 & 10 \\
13 & 6 \\
14 & 4\end{array}$ & $\begin{array}{rr}1 & 3 \\
1 & 3 \\
1 & 7 \\
1 & 6 \\
1 & 11\end{array}$ & $\begin{array}{rr}15 & 7 \\
16 & 0 \\
16 & 11 \\
17 & 6 \\
18 & 11\end{array}$ & $\begin{array}{ll}1 & 10 \\
1 & 10 \\
1 & 11 \\
1 & 11 \\
1 & 10\end{array}$ & $\begin{array}{rr}18 & 3 \\
18 & 14 \\
19 & 10 \\
20 & 0 \\
21 & 13\end{array}$ & $\begin{array}{lr}2 & 0 \\
1 & 13 \\
2 & 1 \\
1 & 14 \\
2 & 8\end{array}$ & $\begin{array}{ll}20 & 4 \\
21 & 6 \\
22 & 0 \\
22 & 8 \\
23 & 15\end{array}$ & $\begin{array}{rr}2 & 2 \\
1 & 13 \\
2 & 6 \\
2 & 1 \\
2 & 4\end{array}$ \\
\hline
\end{tabular}

* The differences between the means of each group are all statistically significant, i.e. more than three times the standard error of the difference.

TABLE III

WEIGHT INCREMENTS IN THE First YeAR OF LifE COMPARISON OF BOYS AND GIRLS IN SIX BIRTH-WEIGHT GROUPS

\begin{tabular}{|c|c|c|c|c|c|c|c|c|c|c|c|c|c|c|c|c|c|c|}
\hline \multirow{3}{*}{ Sex } & \multirow{3}{*}{\multicolumn{2}{|c|}{$\begin{array}{l}\text { Group } \\
\text { Number }\end{array}$}} & \multirow{2}{*}{\multicolumn{2}{|c|}{$\begin{array}{c}\text { Average } \\
\text { Birth } \\
\text { Weight }\end{array}$}} & \multirow{3}{*}{$\begin{array}{c}\text { Total } \\
\text { Numbers }\end{array}$} & \multicolumn{13}{|c|}{ Average Increments of Weight } \\
\hline & & & & & & \multicolumn{2}{|c|}{$\begin{array}{l}\text { Birth- } \\
1 \text { month }\end{array}$} & \multicolumn{2}{|c|}{$\begin{array}{c}1-3 \\
\text { months }\end{array}$} & \multicolumn{3}{|c|}{$\begin{array}{c}3-6 \\
\text { months }\end{array}$} & \multicolumn{2}{|c|}{$\begin{array}{c}6-9 \\
\text { months }\end{array}$} & \multicolumn{2}{|c|}{$\begin{array}{c}9-12 \\
\text { months }\end{array}$} & \multicolumn{2}{|c|}{$\begin{array}{c}0-12 \\
\text { month }\end{array}$} \\
\hline & & & lb. & oz. & & lb. & oz. & lb. & oz. & lb. & oz & & lb. & oz. & lb. & oz. & lb. & $\mathbf{o z}$ \\
\hline \multirow[t]{2}{*}{ Boys } & . & $\begin{array}{r}5 \\
6 \\
7 \\
8 \\
9 \\
10\end{array}$ & $\begin{array}{l}4 \\
6 \\
7 \\
8 \\
8 \\
9\end{array}$ & $\begin{array}{r}14 \\
2 \\
2 \\
0 \\
14 \\
15\end{array}$ & $\begin{array}{r}25 \\
83 \\
193 \\
197 \\
126 \\
38\end{array}$ & $\begin{array}{l}2 \\
1 \\
1 \\
1 \\
0 \\
0\end{array}$ & $\begin{array}{r}1 \\
7 \\
8 \\
6 \\
14 \\
15\end{array}$ & $\begin{array}{l}3 \\
4 \\
4 \\
4 \\
4 \\
4\end{array}$ & $\begin{array}{l}3 \\
3 \\
2 \\
1 \\
3 \\
0\end{array}$ & $\begin{array}{l}4 \\
4 \\
4 \\
4 \\
4 \\
4\end{array}$ & $\begin{array}{r}3 \\
8 \\
7 \\
7 \\
10 \\
9\end{array}$ & & $\begin{array}{l}3 \\
3 \\
2 \\
3 \\
3 \\
3\end{array}$ & $\begin{array}{r}6 \\
5 \\
15 \\
4 \\
3 \\
7\end{array}$ & $\begin{array}{l}2 \\
2 \\
2 \\
2 \\
2 \\
2\end{array}$ & $\begin{array}{r}4 \\
6 \\
3 \\
7 \\
11 \\
10\end{array}$ & $\begin{array}{l}15 \\
15 \\
15 \\
15 \\
15 \\
15\end{array}$ & $\begin{array}{r}1 \\
13 \\
3 \\
9 \\
9 \\
9\end{array}$ \\
\hline & & All boys & 7 & 10 & 662 & 1 & 6 & 4 & 1 & 4 & 7 & 7 & 3 & 4 & 2 & 6 & 15 & 8 \\
\hline \multirow[t]{2}{*}{ Girls } & 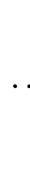 & $\begin{array}{r}5 \\
6 \\
7 \\
8 \\
9 \\
10\end{array}$ & $\begin{array}{l}5 \\
6 \\
7 \\
7 \\
8 \\
9\end{array}$ & $\begin{array}{r}1 \\
2 \\
0 \\
15 \\
13 \\
14\end{array}$ & $\begin{array}{r}33 \\
96 \\
213 \\
195 \\
69 \\
14\end{array}$ & $\begin{array}{l}1 \\
1 \\
1 \\
1 \\
0 \\
0\end{array}$ & $\begin{array}{r}6 \\
4 \\
5 \\
0 \\
15 \\
14\end{array}$ & $\begin{array}{l}3 \\
3 \\
3 \\
3 \\
3 \\
3\end{array}$ & $\begin{array}{r}13 \\
10 \\
9 \\
11 \\
10 \\
8\end{array}$ & $\begin{array}{l}4 \\
4 \\
4 \\
4 \\
4 \\
4\end{array}$ & $\begin{array}{l}5 \\
7 \\
2 \\
1 \\
0 \\
7\end{array}$ & $\begin{array}{l}5 \\
7 \\
2 \\
1 \\
0 \\
7\end{array}$ & $\begin{array}{l}3 \\
2 \\
2 \\
2 \\
2 \\
3\end{array}$ & $\begin{array}{r}0 \\
12 \\
14 \\
15 \\
10 \\
2\end{array}$ & $\begin{array}{l}1 \\
2 \\
2 \\
2 \\
2 \\
2\end{array}$ & $\begin{array}{r}14 \\
1 \\
8 \\
6 \\
8 \\
2\end{array}$ & $\begin{array}{l}14 \\
14 \\
14 \\
14 \\
13 \\
14\end{array}$ & $\begin{array}{r}6 \\
2 \\
6 \\
1 \\
11 \\
1\end{array}$ \\
\hline & & All girls & 7 & 6 & 620 & 1 & 2 & 3 & 9 & 4 & 3 & 3 & 2 & 14 & 2 & 6 & 14 & 2 \\
\hline
\end{tabular}


(B) ANalysis by Birth Weight

When the records for the six birth-weight groups were examined the following facts emerged (see Table II).

(1) Except in the case of very small babies (Group 5), boys and girls in the same birth-weight groups had grown at different rates.

(2) The birth-weight groups for each sex retained their rank order throughout the period of study. This finding showed that the babies who were largest at birth had still retained their lead at the end of a year.

(3) The differences between the birth-weight groups remained approximately the same at each age. Fig. 1 shows that once the lines representing the serial mean weights of the boys in each birthweight group are well established, they tend to run parallel. The corresponding record for the girls (unpublished) also shows parallel lines but here the lines are less steep owing to the slower rate of growth.

The implication of this finding is that the actual amount of weight gained in each age period was greater for the boys than for the girls, but after the first month it was approximately the same for large and small babies of the same sex (see Table III). In Table III the actual weight increments for each age period are shown for the two sexes and six birth-weight groups. If the boys in Groups 6 and 9 are compared it will be seen that they both gained the same amount of weight between one and three months; thereafter the successive increments varied by 2 oz., 2 oz. and 5 oz.

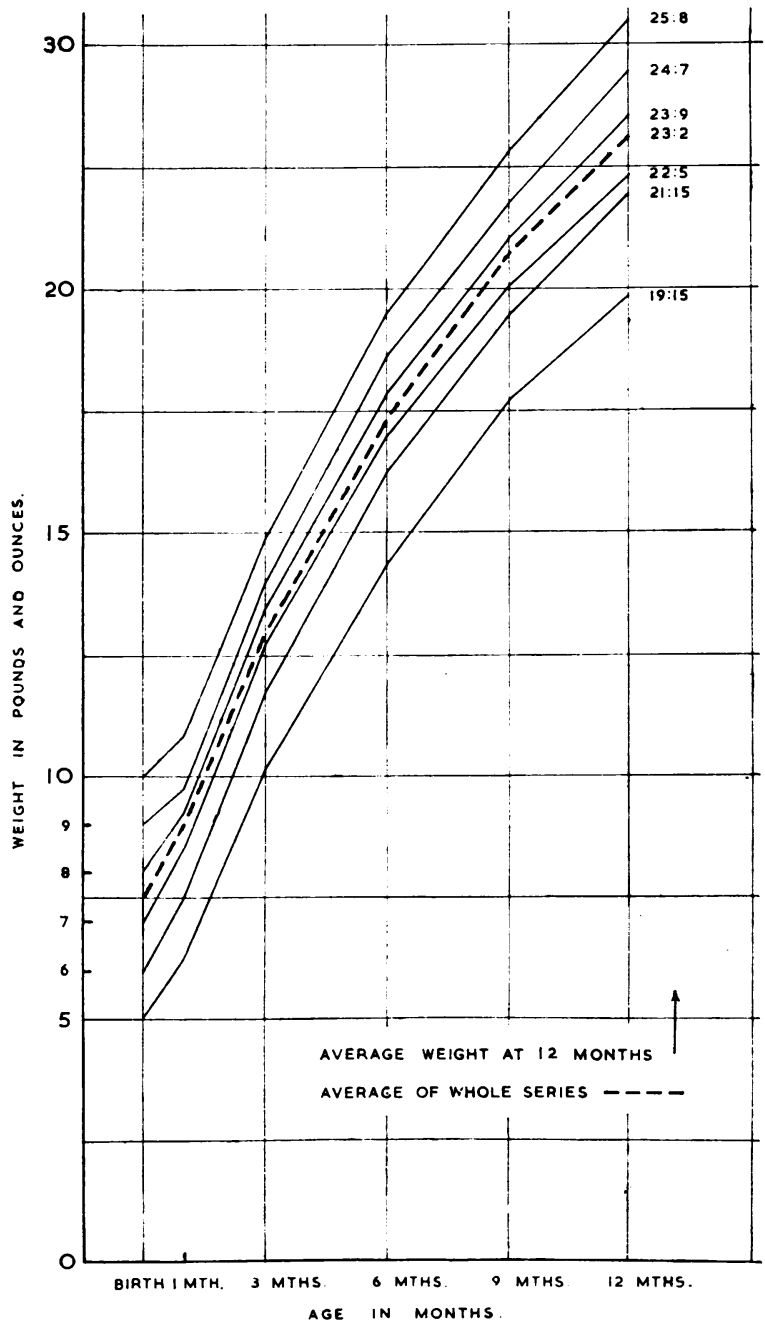

FIG. 1.-Average weight gain in the first year of life. Comparison of six birth-weight groups (boys only). 
respectively. If the girls in Groups 7 and 8 are compared, even smaller differences will be seen. In other words, although sex had had an appreciable effect on the absolute amount of weight gained, the effect of birth weight appears

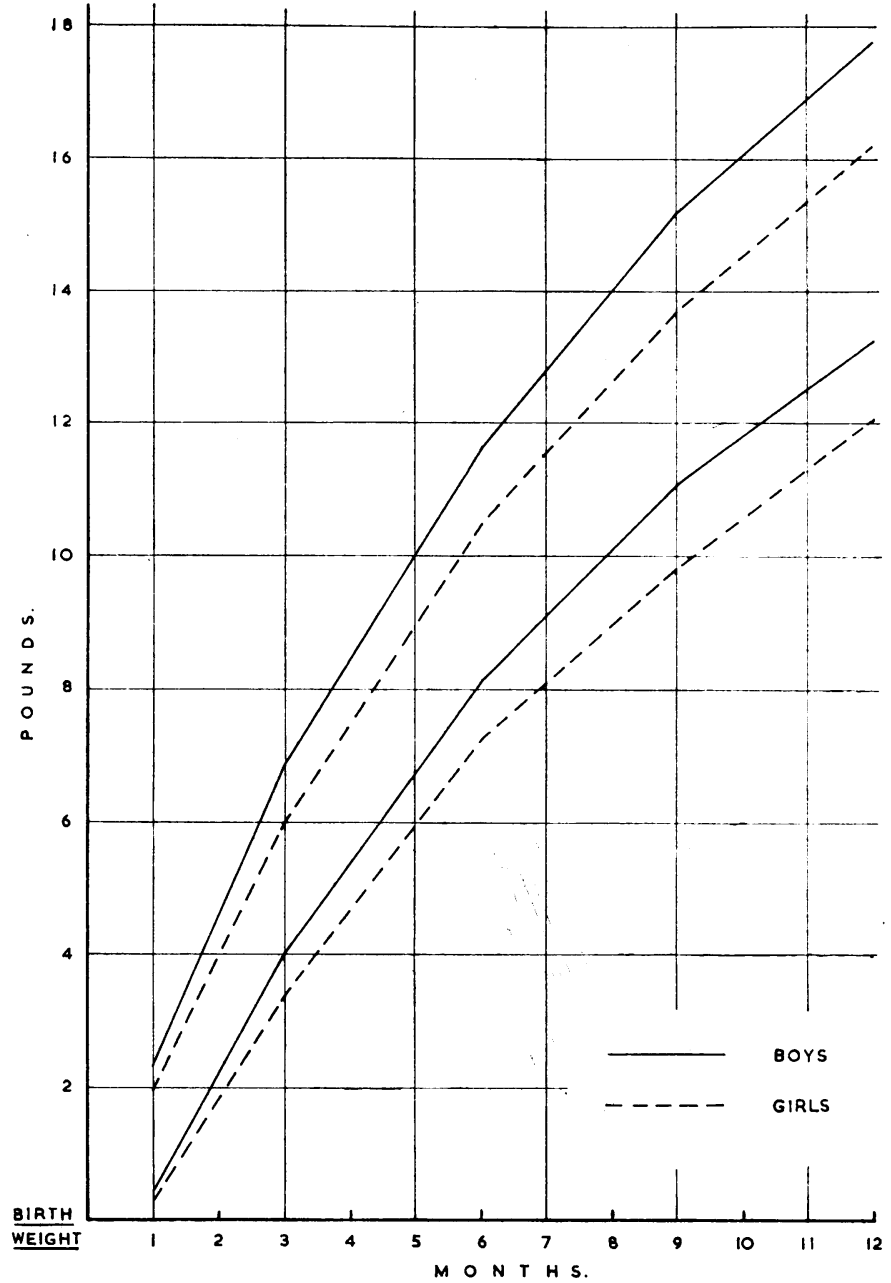

FIG. 2.-Zones* of average weight increment for boys and girls during the first year of life, birth weight taken as zero. to have been negligible.

A simple demonstration of the difference between the boys and the girls is given in Table IV and Fig. 2. In the former the average weight increments for each age period have been taken from Table III to make a set of cumulative figures. Here it will be seen that the boys gained a pound more than the girls during the first six months and increased this to 1 lb. $6 \mathrm{oz}$. by the end of the year.

In Fig. 2 two overlapping zones are shown, one for boys and one for girls. The upper margin of each zone represents the mean cumulative weight increments since birth plus the value of one standard deviation from the mean, and the lower margin the mean cumulative weight increments minus the value of one standard deviation from the mean. In other words, each zone embraces approximately 68 per cent. of the records. In this figure the lines representing the mean values (which are shown in Table IV) have been omitted since their absence makes for clarity. 
Finally, the records of John S., one of the boys who attended the Institute of Social Medicine, have been entered beside the averages and standard deviations given in Table IV.

Comparison OF ONe Boy With The Average

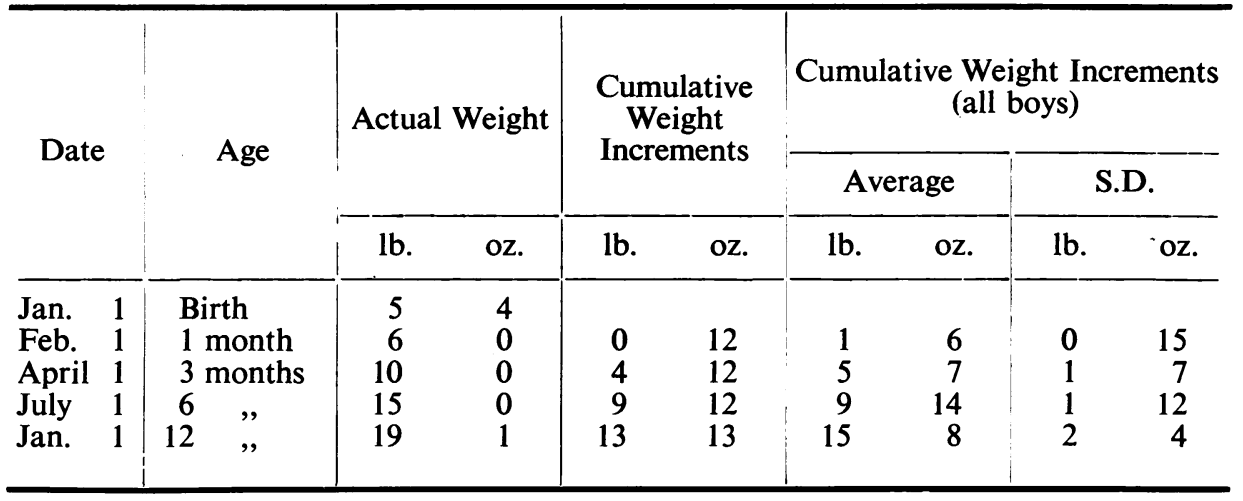

If the weight increments of this boy, which do not differ by more than one standard deviation from the mean increments, had been plotted in the earlier chart (Fig. 2) they would have fallen within the zone taken as normal in spite of the fact that the figures for actual weights are well below the average (see Table I). In other words, although this baby was unusually small he appears to have grown at a normal rate.

TABLE IV

Cumulative Weight Increments in the First Year of Life BOYS AND GIRLS

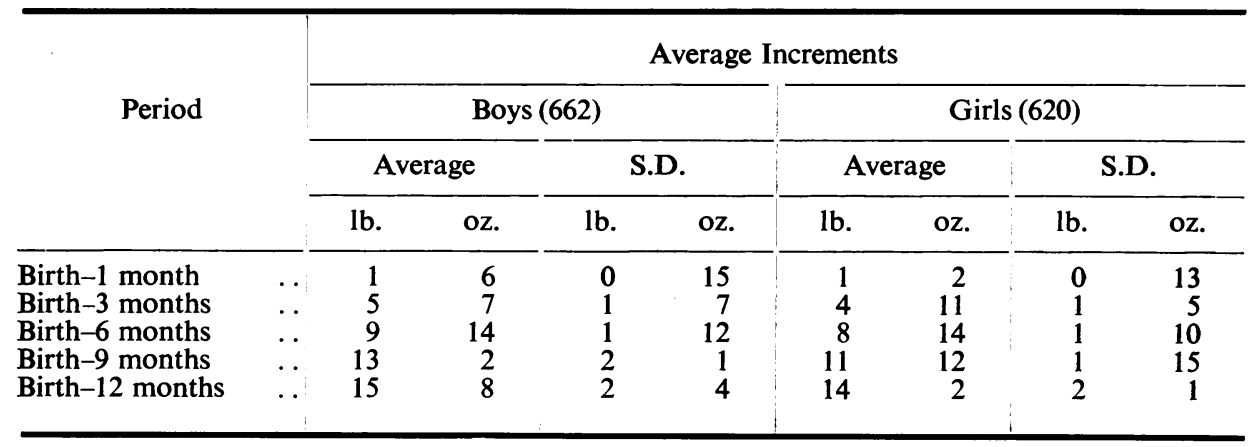

\section{Comparison of Present Findings with Other Records}

(1) There is a household dictum, widely quoted in medical and nursing text-books, to the effect that " a baby should double its birth weight in five to six months, and treble it in a year" (Paterson, 1947; Garrod, Batten, and Thursfield, 1947; 
Mitchell, 1949; Meering, 1947). In Table V the weights recorded in the present investigation are compared with those which would be expected from this formula. With three exceptions the figures obtained in the present investigation give average weights at six months which exceed the expected weights. At twelve months the differences between the two sets of figures are even greater; the observed values ranging from $5 \mathrm{lb}$. above, to $6 \mathrm{lb}$. below, the expected amount.

TABLE V

Weights IN THE First Year of Life

(C) COMPARISON OF OBSERVED AND "EXPECTED "* WEIGHTS AT 6 AND 12 MONTHS FOR BOYS AND GIRLS IN SIX BIRTH-WEIGHT GROUPS

\begin{tabular}{|c|c|c|c|c|c|c|c|c|c|c|c|}
\hline \multirow{4}{*}{$\begin{array}{c}\text { Group } \\
\text { Number }\end{array}$} & \multirow{3}{*}{\multicolumn{2}{|c|}{$\begin{array}{c}\text { Average } \\
\text { Birth Weight } \\
\text { (boys and } \\
\text { girls together) }\end{array}$}} & \multirow{4}{*}{ Totals } & \multicolumn{8}{|c|}{ Average Weights } \\
\hline & & & & \multicolumn{4}{|c|}{6 months } & \multicolumn{4}{|c|}{12 months } \\
\hline & & & & \multicolumn{2}{|c|}{ Actual } & \multicolumn{2}{|c|}{ Expected* } & \multicolumn{2}{|c|}{ Actual } & \multicolumn{2}{|c|}{ Expected* } \\
\hline & lb. & oz. & & lb. & oz. & lb. & oz. & lb. & oz. & lb. & oz. \\
\hline \multirow{2}{*}{5} & \multirow{2}{*}{4} & \multirow{2}{*}{15} & Boys (25) & 14 & 5 & \multirow{2}{*}{9} & \multirow{2}{*}{14} & 19 & 15 & \multirow{2}{*}{14} & \multirow{2}{*}{13} \\
\hline & & & Girls (33) & 14 & 9 & & & 19 & 7 & & \\
\hline \multirow{2}{*}{6} & \multirow{2}{*}{6} & \multirow{2}{*}{2} & Boys (83) & 16 & 4 & \multirow{2}{*}{12} & \multirow{2}{*}{4} & 21 & 15 & \multirow{2}{*}{18} & \multirow{2}{*}{6} \\
\hline & & & Girls (96) & 15 & 7 & & & 20 & 4 & & \\
\hline \multirow{2}{*}{7} & \multirow{2}{*}{7} & \multirow{2}{*}{1} & Boys (193) & 17 & 3 & \multirow{2}{*}{14} & \multirow{2}{*}{2} & 22 & 5 & \multirow{2}{*}{21} & \multirow{2}{*}{3} \\
\hline & & & Girls (213) & 16 & 0 & & & 21 & 6 & & \\
\hline \multirow{2}{*}{8} & \multirow{2}{*}{7} & \multirow{2}{*}{15} & Boys (197) & 17 & 14 & \multirow{2}{*}{15} & & 23 & 9 & & \\
\hline & & & Girls (195) & 16 & 11 & & 14 & 22 & 0 & 25 & 13 \\
\hline 0 & 8 & 14 & Boys (126) & 18 & 9 & 17 & 10 & 24 & 7 & 2 & 10 \\
\hline 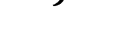 & & 17 & Girls (69) & 17 & 6 & 17 & 12 & 22 & 8 & 20 & 10 \\
\hline & 0 & 15 & Boys (38) & 19 & 7 & 10 & 14 & 25 & 8 & & \\
\hline & & & Girls (14) & 18 & 11 & & & 23 & 15 & & \\
\hline
\end{tabular}

* " Expected" weight at 6 months $=$ Birth weight $\times 2$

" Expected" weight at 12 months $=$ Birth weight $\times 3$.

(2) The National Association for Maternity and Child Welfare publishes a chart for use in Welfare Clinics on which a line marked " normal weight (approximate only)" runs from $7 \frac{1}{4} \mathrm{lb}$. at birth through $14 \frac{1}{2} \mathrm{lb}$. at six months to $21 \frac{1}{4} \mathrm{lb}$. at one year. In Figs 3 and 4 (opposite) this is shown as a horizontal line crossing the centre of the diagram. Cutting across it at various points are a series of shaded areas representing the main bulk of the records for each of the birthweight groups in the present series (i.e. all values lying within \pm 2 standard deviations from the means). In this way it is possible to compare the observed weights 


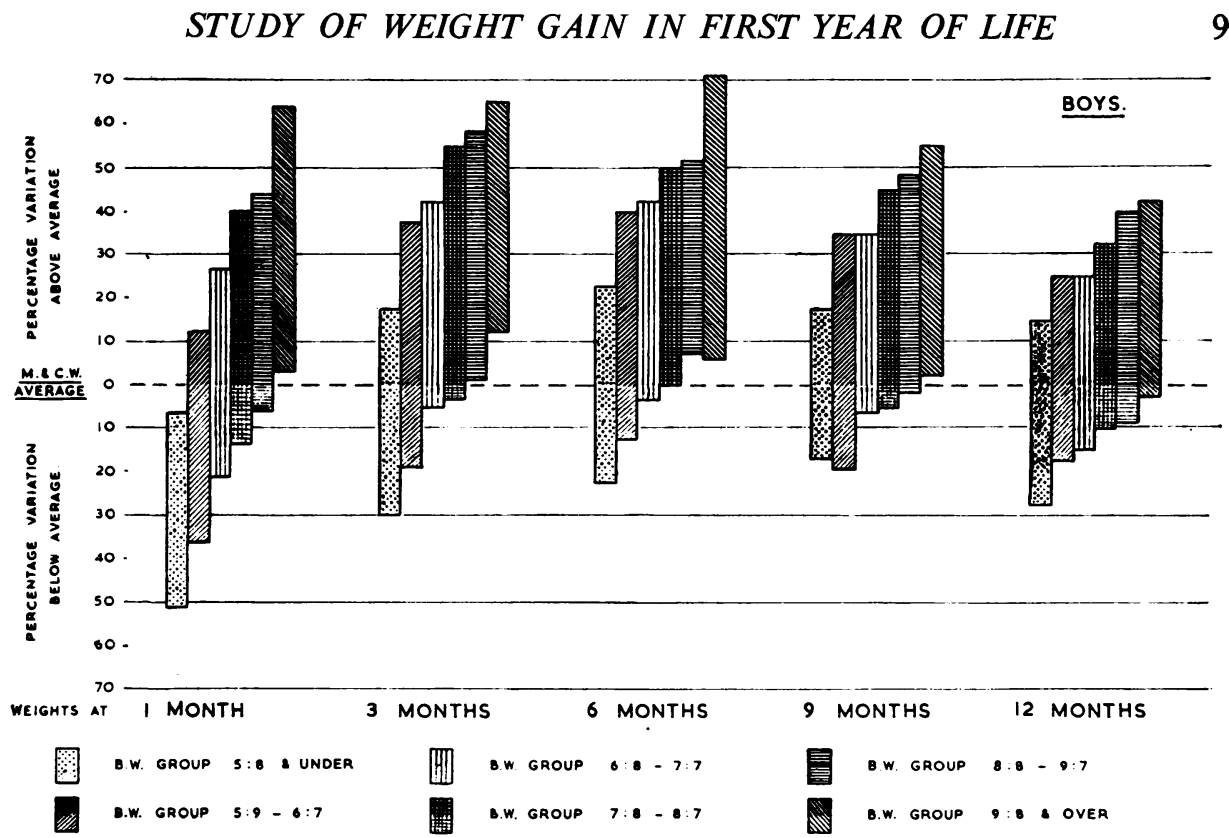

Fig. 3.-Comparison of weight range* of six birth-weight groups in the first year of life with standard used by the National Association for Maternity and Child Welfare (boys only).

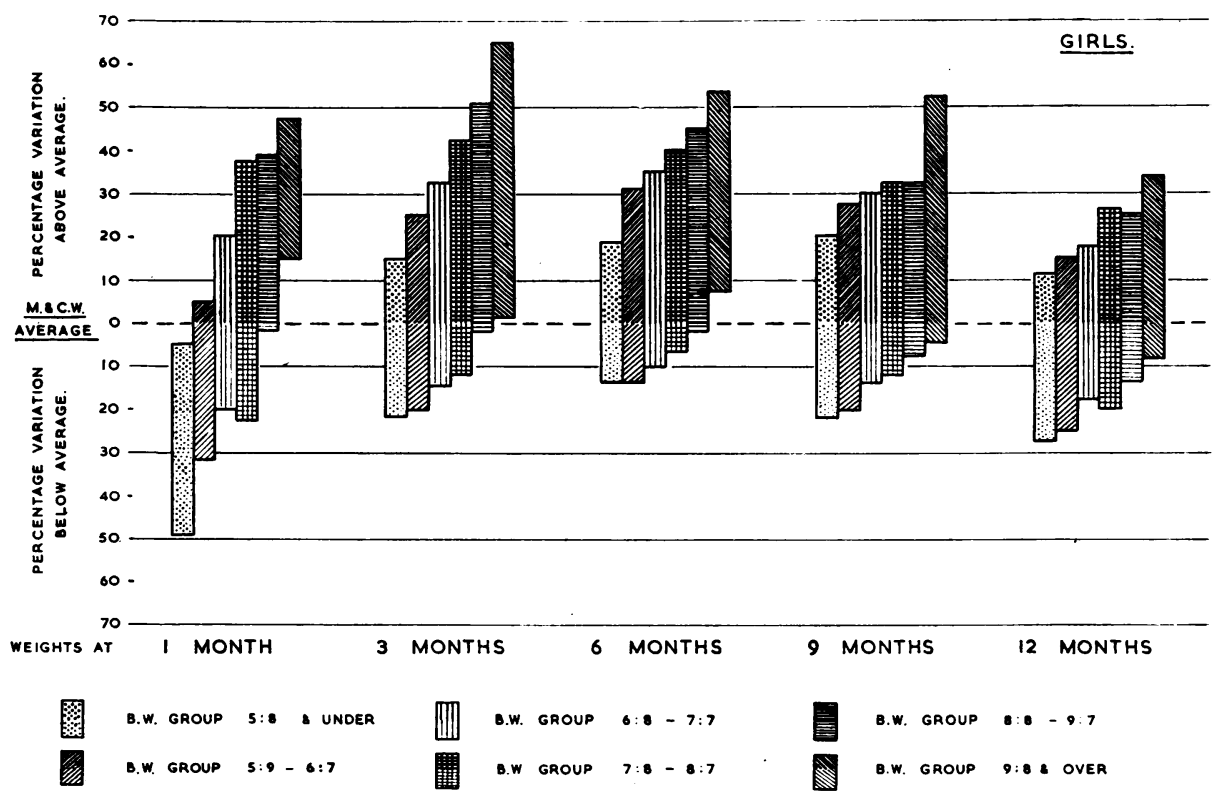

FIG. 4.- Comparison of weight range* of six birth-weight groups in the first year of life with standard used by the National Association for Maternity and Child Welfare (girls only).

* This range includes 95 per cent. of observations. 
for the boys and girls with the so-called "normal weight" record of a baby weighing $7 \frac{1}{4} \mathrm{lb}$. at birth.

According to this demonstration, the range of wejghts at 3 months and 6 months for boys in Group 7 (average birth weight $716.2 \mathrm{oz}$.) extends from 42 per cent. above to 5 per cent. below the average line. For girls in Group 7 it extends from 32 per cent. above to 15 per cent. below at 3 months, and from 35 per cent. above to 10 per cent. below at 6 months. In other birth-weight groups even greater deviations from the horizontal line can be seen. In other words, a majority of the records obtained in the present investigation differ markedly from the so-called " normal weight"; first because the latter makes no allowance for sex difference; secondly because it assumes that the rate of growth (as opposed to the actual weight increments) is independent of birth weight, and thirdly because it does not fit the mean values for boys and girls in Group 7, although it is supposed to indicate the average weights of a baby weighing $7 \mathrm{lb}$. at birth.

(3) Paterson (1947) makes this statement:

By the 10th or 12th day, the birth weight is regained. Thereafter, from 6 to 8 oz. a week are gained for the first 5 months and about 4 oz. a week from 5 months to one year.

According to these standards, babies should gain from 8 to $11 \mathrm{lb}$. in the first six months and from $14 \frac{1}{2}$ to $17 \frac{1}{2} \mathrm{lb}$. in twelve months. This range of values applies to about half the babies in the present series, but 17 per cent. of the boys and 39 per cent. of the girls fell short of the expected range in the first six months, and 31 per cent. and 5 per cent. respectively, exceeded the upper limits at twelve months.

According to another set of figures (Paterson, 1947), the average weight gain during the first six months is $8 \frac{1}{2} \mathrm{lb}$. for boys and girls, and during the second six months $5 \mathrm{lb}$. for boys and $4 \frac{1}{2} \mathrm{lb}$. for girls. These figures also differ from the findings of the present investigation, which might be summed up thus:

Boys gain $10 \mathrm{lb}$. in the first six months of life and $5 \frac{1}{2} \mathrm{lb}$. more in the second; girls gain $9 \mathrm{lb}$, in the first six months and $5 \mathrm{lb}$. more in the second. (See Table VI).

TABLE VI

Weight Gains in the First Year of Life for Boys and Girls at Quarterly, Monthly, and WEEKLY INTERVALS

\begin{tabular}{|c|c|c|c|c|c|c|c|c|c|c|c|c|c|}
\hline \multirow{4}{*}{ Period } & \multicolumn{13}{|c|}{ Average Weight Gains } \\
\hline & \multicolumn{7}{|c|}{ Boys } & \multicolumn{6}{|c|}{ Girls } \\
\hline & \multicolumn{3}{|c|}{ Quarterly } & \multicolumn{2}{|c|}{ Monthly } & \multicolumn{2}{|c|}{ Weekly } & \multicolumn{2}{|c|}{ Quarterly } & \multicolumn{2}{|c|}{ Monthly } & \multicolumn{2}{|c|}{ Weekly } \\
\hline & & lb. & oz. & lb. & oz. & lb. & oz. & lb. & oz. . & lb. & oz. & lb. & oz. \\
\hline $\begin{array}{l}2 \text { weeks }-3 \text { months } \\
3-6 \text { months }\end{array}$ & $\begin{array}{l}. \\
\cdots \\
\cdots \\
. .\end{array}$ & $\begin{array}{l}5 \\
4 \\
3 \\
2\end{array}$ & $\begin{array}{l}7 \\
7 \\
4 \\
6\end{array}$ & $\begin{array}{l}1 \\
1 \\
1 \\
0\end{array}$ & $\begin{array}{r}13 \\
8 \\
1 \\
13\end{array}$ & $\begin{array}{l}0 \\
0 \\
0 \\
0\end{array}$ & $\begin{array}{l}8 \\
5 \frac{1}{2} \\
4 \\
3\end{array}$ & $\begin{array}{l}4 \\
4 \\
2 \\
2\end{array}$ & $\begin{array}{r}11 \\
3 \\
14 \\
6\end{array}$ & $\begin{array}{l}1 \\
1 \\
0 \\
0\end{array}$ & $\begin{array}{r}9 \\
6 \\
15 \\
13\end{array}$ & $\begin{array}{l}\mathbf{0} \\
\mathbf{0} \\
\mathbf{0} \\
\mathbf{0}\end{array}$ & $\begin{array}{l}7 \\
5 \\
3 \frac{1}{2} \\
3\end{array}$ \\
\hline
\end{tabular}


Discussion

In order to decide whether a baby is growing satisfactorily it is necessary to have not only serial weight records but also a set of " normal " values with which to compare them. It is then possible to assess progress either by comparing the actual and the " expected " weights at given ages, or by comparing the proportional increase of the actual and expected weights at different ages (i.e. the rates of growth). Since the actual weight of a baby during the first year of its life is determined partly by birth weight and partly by sex, it is evident that to assess growth in terms of actual or relative weights it is necessary not only to have a separate set of expected values for boys and girls but also to have separate sets of figures for different birth weights.

Thus a set of standards for absolute and relative weights, based on the present findings, would read as follows for a boy weighing $5 \mathrm{lb}$. at birth:

$10 \mathrm{lb}$., or twice his birth weight, at three months;

$14 \frac{1}{2} \mathrm{lb}$., or 2.9 times his birth weight, at six months;

$20 \mathrm{lb}$., or 4 times his birth weight, at a year.

But twelve sets of figures would be required to describe the expected weights if all babies were grouped in six birth-weight groups (1-lb. intervals), 24 sets if classed in twelve groups ( $\frac{1}{2}-\mathrm{lb}$. intervals), and so on.

It is, however, possible to assess progress in another way, namely by recording weight increments or the actual amount of weight gained in a given period of time. For clinic purposes this method has a two-fold advantage over the others. In the first place the figures recorded are not affected by differences in birth weight, and secondly, if our findings are typical, " normal " weight increments between one month and twelve months are approximately the same for large and small babies. It is therefore possible to formulate a set of expected values in which a single figure for each age period represents the mean value for all babies of the same sex. A range of expected values can also be indicated by stating the standard deviation from the mean, as well as the mean value. In practice, however, it would probably be simpler to have a chart (similar to that shown in Fig. 2) on which the birth weight is recorded as zero and the normal or expected range of values for weight increments is indicated by a zone. Armed with such a chart even an inexperienced observer could decide whether or not a baby was gaining weight satisfactorily.

\section{SUMMARY}

(1) A study of growth during the first year of life is described in which serial weight records of 1,282 babies born in Oxford between 1944 and 1948 are analysed in relation to sex and birth weight.

(2) The rate of growth was found to be greater for boys than for girls, and greater for small babies than for large.

(3) These differences appeared to be due to the fact that weight increment (i.e. actual amount of weight gained since birth) is a function of sex but not of size 
(i.e. birth weight) and, other things being equal, tends to be the same for all babies of the same sex between the ages of one month and one year.

(4) The latter finding suggests a simple yard-stick of growth which could be incorporated in the progress charts used in Infant Welfare Clinics.

My thanks are due to Dr. Mary Fisher, Senior Assistant Medical Officer in charge of Maternity and Child Welfare to the City of Oxford, and to Miss M. B. Wood, S.R.N., S.C.M., Superintendent of the Oxford Mothercraft Clinic, for granting me access to their records. I should also like to record my gratitude to Dr. Alice Stewart, Acting Director of the Institute of Social Medicine, for her constant encouragement and help in the preparation of this paper, and to my other colleagues in the Institute for their assistance. The figures were drawn by Mr. L. E. Griffith.

\section{REFERENCES}

Asher, C., and Roberts, J. A. F. (1949). British Journal of Social Medicine, 3, 56.

Garrod, A. E., Batten, F. E., and Thursfield, H. (1947). "Diseases of Children ”, ed. D. Paterson and A. Moncrieff, 4th ed. Arnold, London.

Meering, A. B. (1947). "Handbook for Nursery Nurses', 1st ed. Baillière, Tindall, and Cox, London.. Mitchell, A. W. (1949). "Pediatrics and Pediatric Nursing", ed. R. A. Lyon and E. A. Wallinger.. 3rd ed. Saunders, London and Philadelphia.

Paterson, D. (1947). " "Sick Children", 6th ed. Cassell, London.

Registrar-General's Decennial Supplements, England and Wales (1911-1931). H.M.S.O., London. Thwaites, E. J. (1950). Arch. Dis. Childh., 25, 193. 